\title{
Functionality of Aframomum Danielli Seed Powder Extract in Glycemic Load of Soymilk-Based Juice
}

\author{
A.O. Dauda*, G.O Adegoke \\ Department of Food Technology, University of Ibadan, Ibadan, Oyo State, Nigeria, West Africa \\ *Corresponding author: adegboladauda@yahoo.com
}

Received April 12, 2014; Revised June 03, 2014; Accepted July 04, 2014

\begin{abstract}
Spices are important supplements added to food as flavouring agents and/or a preservative and have been in use all over the world for thousands of years. Various additives have been utilised over the years to spice our food products. Synthetic additives, which have been in use, have come with various side effects, hence the need to shift focus to the use of natural ones. Research into the production and utilization of indigenous food additives on a large scale has not been undertaken in Nigeria. Even its utilization in food products to prevent or reduce food related ailments or diseases have not really been done. This present work investigates the health benefits of the spice's extract on the glycemic load (GL) of the juice to consumers. Standard method was used for extraction of juice from carrot, watermelon and pawpaw. Standard method [8] was equally used for the proximate composition (moisture content, protein, fat, carbohydrate, crude fibre and ash), while soymilk was made from soybeans under laboratory condition. The juices from the vegetable (carrot), fruits (watermelon and pawpaw), and soymilk were blended in equal ratios and thereafter treated with $A$. danielli extract (1g-3g). Glycemic load (GL) of the samples was determined by multiplying the weighted average of the glycemic indexes (GIs) of the mixed meal by the available carbohydrate and dividing the product by 100 . Available carbohydrate was determined by subtracting the fibre content from the total carbohydrate. GL of untreated samples was 10.26, while treated samples recorded low values (6.11-7.20). Standard values were 1-10, low GL; 10.1-20, medium GL; above 20.1 and above, high GL. The outcome of the work could assist in utilising local spices for the full benefit of consumers.
\end{abstract}

Keywords: A. danielli, soymilk-based juice, glycemic load, proximate analysis

Cite This Article: A.O. Dauda, and G.O Adegoke, "Functionality of Aframomum Danielli Seed Powder Extract in Glycemic Load of Soymilk-Based Juice.” American Journal of Food Science and Technology, vol. 2, no. 3 (2014): 98-102. doi: 10.12691/ajfst-2-3-4.

\section{Introduction}

Fruits and vegetables are among the most important foods of mankind as they are not only nutritive but are also indispensable for the maintenance of health. They are able to decrease the risk of cardiovascular diseases and cancer [5]. Apart from their nutritional and sensory properties, fruits and vegetables are currently recognised as active and protective agents [49].

Fruits and vegetables are low in calories and fat. Consumers relish juice drinks, and in a bid to meet consumer's demands, fruit and vegetable juices are produced in large quantities and mostly preserved and sweetened with sweeteners such as Sucrose, Honey etc which tends to increase the blood sugar of consumers. As a result of this, consumers of fruit and vegetable juices are prone to diabetes or other similar ailments when juices are consumed frequently and over time. The assertion was corroborated by $[53,54]$ when they reported high level of obesity amongst children, as a result of consuming fruit juices.

Soymilk (also called soyamilk, or soybean juice and sometimes referred to as soydrink/beverage) is a beverage made from soybeans (Glycine max). It is a stable emulsion of oil, water, and protein. Soymilk is produced by soaking dry soybeans and grinding with water before cooking at boiling point for about 20 minutes. Soymilk contains similar proportion of protein as cow's milk; around 3.5\% and $2 \%$ fat, $2.9 \%$ carbohydrate, and $0.5 \%$ ash. They have been blended with other food products to produce other products, most likely, with better nutritional qualities. Milk-based products all contain actual milk (and/or soymilk) or different combinations of modified proteins. Most of the popular milk-based beverages are good sources of protein, containing 10 to 40 grammes per serving.

Carbohydrates fall into two categories: simple (including sugar, honey and maple syrup) and complex (including whole grains, starchy vegetables and legumes). Carbohydrates will turn into sugar and raise blood sugar (glucose) levels the body's source of energy for most activities [31]. Not all carbohydrate foods are created equal; in fact they behave quite differently in our bodies. The GI describes this difference by ranking carbohydrates according to their effect on our blood glucose levels. Choosing low GI carbohydrate, the one that produce a very small fluctuation in our blood glucose and insulin levels, is the secret to long term health reducing your risk of health diseases and diabetes and is the key to sustainable weight loss. 
Glycemic index (GI) or glycemic load (GL) is a measure of the rate of surge of blood sugar of consumers. GI is a specific indicator of blood glucose response, but not the only parameter that affect blood sugar. Blood sugar can either be low, medium or high in value. Foods with low GI provide a variety of healthy benefits. Low GI modestly decreased serum triglycerides and cholesterol in non-diabetic as well as those with non insulin dependent diabetes mellitus $[32,44]$. Control of blood sugar help in the management of diabetes mellitus, especially Type 2 Diabetes Mellitus (T2DM) and reducing chronic complications associated with the disease [6,35,52].

Spices are flavour imparting plant materials and contribute greatly to the daily antioxidant intake in most diets [15]. Spices are derived from different parts of specific plants such as the barks, flowers, roots, seeds and fruits. Aframomum danielli seeds are smooth, shinning olive-brown with a turpentine-like taste and are used medicinally. Spices have been shown to confer health benefits and have been proven to counteract oxidative stress in vitro and in vivo $[2,45,46,47,61,68]$. The nutritional profile of $A$. danielli had been reported by [4], essential oils of the seed reported by [3], antimicrobial activities of the crude extracts of $A$. danielli against a number of micro-organisms have also been reported $[4,21]$.

As a result of the reported numerous properties of $A$. danielli, and the need to curb or seriously reduce the prevalence of diseases associated with the consumption of sweetened juices and other food products, this paper reports on the findings of the effect of powder extract of $A$. danielli seeds on the glycemic load of consumers of soymilk-based juice.

\section{Materials and Methods}

A. danielli pods were purchased from a local market in Ibadan. The seeds were removed from the pods and cleaned of the extraneous materials. The seeds were winnowed and milled into powder using hammer mill. The powder was then sieved with a wire-mesh to obtain fine powder and stored at room temperature for use.

\section{* Beverage Preparation}

Fresh pawpaw was collected from a farm at Ajibode Village in Ibadan. Carrot and watermelon were purchased from Sabo in Ibadan, while the soybean used in producing the soymilk were sourced from International Institute for Tropical Agriculture (IITA) in Ibadan.
Fresh, juicy, good quality fruits (watermelon and pawpaw) and vegetable (carrot) were sorted for processing. The fruits and vegetable were washed thoroughly under tap water to remove foreign materials before juices were extracted from them. The sourced soybeans were cleaned properly, soaked in water (at $30^{\circ} \mathrm{C}$ for 5 hours), grinded (with hammer mill), slurry cooked (at boiling point for 20 minutes), separation of the cooked soymilk from fibre and boiling of the resulting filtrate to obtain the soymilk. Juices from pawpaw, watermelon and carrot and soymilk were blended in equal ratios and then treated with powdered extract of $A$. danielli (1.0-3.0g).

Proximate Analyses: The moisture, protein, carbohydrate, fat, crude fibre and ash contents of the samples were determined using standard methods.

\section{Determination of Glycemic Load}

Glycemic index (GI) is a new method of classifying foods based on the blood glucose response after food consumption. Published GI ranking are: GI of 70+ (high), GI of 56-69 (moderate) and GI of 55 and less (low) [69]. Glycemic load (GL) on the other hand is the weight of glucose which raises blood glucose by the same amount and defined mathematically as g X GI/100 [57], [24]. High GL food (GL of 20+), moderate GL (11-19) and low GL (10 and less).

The published GI figures were used in combination with the proximate composition of the samples. The available carbohydrate (AC) less fibre in serving of the samples was known by determining the proximate analysis of the various samples. The figure (AC value) was multiplied by the standard GI value (published GI estimates) for that particular food and divided by 100 .

$$
\begin{aligned}
& \text { Available Carbohydrate }=\text { Total Carbohydrate }- \text { Fibre } \\
& \mathrm{GL}=\frac{\text { GI x Available Carbohydrate }}{100}
\end{aligned}
$$

GI of mixed meal is assumed to be the weighted average of the GI's of the individual food in the meal.

\section{Results and Discussion}

\section{Proximate Composition of the Samples}

Table 1 shows the proximate composition of the treated and untreated samples. The values were used in calculating the glycemic load of the treated and untreated samples.

\begin{tabular}{|c|c|c|c|c|c|c|}
\hline Sample & Moisture (\%) & Crude Protein (\%) & Fat $(\%)$ & Carbohydrate (\%) & Crude Fibre (\%) & Ash (\%) \\
\hline $\mathrm{R}$ & 70.9 & 2.12 & 0.496 & 22.144 & 2.12 & 2.22 \\
\hline $\mathrm{CWPS}_{3.0}$ & 70.3 & 2.77 & 0.110 & 18.860 & 4.82 & 3.14 \\
\hline $\mathrm{CWPS}_{2.0}$ & 71.4 & 2.52 & 0.121 & 18.752 & 4.927 & 2.28 \\
\hline $\mathrm{CWPS}_{1.0}$ & 71.2 & 2.56 & 0.113 & 16.455 & 4.54 & 5.14 \\
\hline
\end{tabular}

Table 1. Proximate Composition of Blends of Carrot, Watermelon, Pawpaw and Soymilk

CWPS: Blend of Carrot, Watermelon, Pawpaw and Soymilk

R: Indicated the Control Sample

Subscript (3.0 - 1.0): Indicated the A. danielli treatments.

\section{Glycemic Load of the Samples}

Table 2 shows the results of the glycemic load of the samples. The treated sample recorded low glycemic load, while the untreated samples recorded medium glycemic load. Report has it that the higher the glycemic load, the more a serving will trigger blood sugar to rise and that frequent consumption of high glycemic load meals can result in perpetual high insulin levels and when insulin levels are high, the hormone responsible for triggering sugar breakdown, glucagons, would be suppressed, as well as the breakdown of fats for energy [31]. 
Table 2. Glycemic Load of the Treated Samples

\begin{tabular}{|c|c|c|c|}
\hline \multirow{2}{*}{ Sample } & \multicolumn{3}{|c|}{ Treatment and Glycemic Load of Samples } \\
\hline & $3 g$ & $2 g$ & $1 \mathrm{~g}$ \\
\hline CWPS & 7.20 & 7.09 & 6.11 \\
\hline $\mathrm{R}$ & 10.26 & 10.26 & 10.26 \\
\hline $\mathrm{R}$ & -Untreated Samples & & \\
\hline CWPS & -Blend of carrot, w & lawpaw & \\
\hline $1 \mathrm{~g}$ & -Samples treated w & nielli ex & \\
\hline $2 g$ & -Samples treated w & nielli ex & \\
\hline $3 g$ & -Samples treated w & nielli ex & \\
\hline
\end{tabular}
extensively studied. The quality of soyprotein has been assessed through several metabolic studies of nitrogen balance [12,41,71], which have demonstrated that soy protein supports nitrogen balance on par with beef and milk proteins. On recent study reported that amino acids from soy protein appear in the serum sooner, but that this may lead to a more rapid breakdown of the amino acids in the liver [14]. Dietary soy consumption has been shown to have beneficial effects on several aspects of human health, including the diseases potentially influenced by dietary GI levels $[13,27,58]$. Soy consumption has been reported to modestly improve plasma lipid profiles [42,72], improve bone health [43], helps reduce menopausal symptoms [29], and slightly reduce the risk of breast [65] and prostrate cancers [70]. The health benefits of dietary soy have been attributed to its isoflavones as well as to the biological actions of its constituent proteins.

However, an additional means of providing health benefits may be through the low GI of soy and soy foods. Soy based foods may be an appropriate part of diets intended to improve control of blood glucose and insulin levels. Consumption of low GI foods rather than high GI foods appears to modestly improve glycemic control by reducing plasma cholesterol, fructosamine, and haemoglobin [55]. It was reported that high GI diet may have adverse health consequences by increasing the risk of chronic diseases through the stimulation of hyperglycemia and hyperinsulinemia [37], risk of cardiovascular disease (CVD) [7,39,64] and type 2 diabetes [10,28,37,56,57,59]. A low GI is reported to have health benefits [10,16,37,51], shown to improve glycemic control in diabetic and nondiabetic subjects $[25,26,30,33]$, and reduce some CVD risk factors [7,23,30,33,38,40].

It was reported that GI values are determined experimentally by feeding human test subjects a fixed portion of the food (after an overnight fast), and subsequently extracting and measuring samples of their blood at specific interval of times. Report also has it that clinical trials are expensive and difficult to conduct, and valuable to obtain further insight into the impact of glycemic index and total carbohydrate intake on body mass index (BMI) from existing data sets derive from carefully conducted observational studies [37,67].

Numerous studies have shown spices to be good source of natural antioxidant possessing digestive stimulant action, bioavailability enhancement nature, carminative, antidiabetic influence, anti-inflammatory ability, anticarcinogenic potential and neuroprotective effect $[1,61,62,63]$. They have equally been reported to have high phytochemicals utilised in preventing diseases and to promote health [18,20,22,50,66,68].
Fruits and vegetables contain simple sugars with a faster rate of absorption into the blood stream than complex ones. The absorption of these sugars into the blood stream probably triggers a great increase in the blood sugar level, which necessitated the determination of the glycemic load of the samples using the values of glycemic index obtained from the published GI figures. Consumers of juice or carbohydrate food with diseases such as diabetes and other health problems have been placed on synthetic drugs for control of the health problems. These synthetic drugs have always come with various attendant problems and are equally expensive and has led to the use of natural plant foods which are not only sources of nutrients and energy provider, but may equally confer health benefits [2,45,46,47,60,61,68]. Low glycemic index/low glycemic load helps people lose and control weight, increase body's sensitivity to insulin, improves diabetes control, reduces the risk of heart disease, and reduces blood cholesterol levels. It equally helps to reduce hunger and keep you fuller for longer, prolong physical endurance and help re-fuel carbohydrate stores after exercise.

Scientific evidence suggests that antioxidants reduce the risk of chronic diseases including cancer and heart diseases [9]. In line with this and coupled with the reported properties of components of soy-based products, spices and fruits, it became imperative to utilize these qualities in the various food products in finding ways of ameliorating the myriads of diseases associated with food consumption. From the research work, it was observed that consumers of samples treated with $1 \mathrm{~g}-3 \mathrm{~g}$ of $A$. danielli extract had low blood sugar when measured compared to when the untreated samples were consumed. The low glycemic load recorded for the treated samples could be attributed to the effectiveness of the spice in regulating the rate of utilisation of the blood sugars i.e inhibiting the hydrolysis of carbohydrate. The hindrance could be attributed to the effectiveness of the active components of the $A$. danielli inhibiting the activities of the enzymes ( $\alpha$-amylase and $\alpha$-glucosidase) responsible for the breakdown or hydrolysis of carbohydrate to simpler sugars, especially breaking it down to oligosaccharides and disaccharides before being converted to monosaccharide, thus regulation and stabilising the release and absorption of sugars into the blood stream $[36,48]$.

It could then be inferred from the results obtained in this research work and other reports on the activities of spices that $A$. danielli extract conferred medicinal benefit on the products.

\section{Conclusion}

Consumption of spice-rich foods and their ingredients could be a more effective way of preventing the various ailments that could occur as a result of consuming fruit juices and other carbohydrate foods. This indigenous products or spices are advantageous because of the absence of side effects, accessibility and cheapness when compared with synthetic ones. I therefore recommend an increase in the consumption of $A$. danielli spiced food products in order to prevent/minimise to the bearest 
minimum the incidence of and/or prevalence of several degenerative diseases.

\section{References}

[1] Adefegha, S.A., Oboh, G., Enhancement of Total phenolics and Antioxidants Properties of Some Tropical Green Leafy Vegetables by Steam Cooking. J. Food Process. Preserve. 2011a, 35(5): 615622.

[2] Adefegha, S.A., Oboh, G., Inhibition of key enzymes linked to type-2 diabetes and sodium nitroprusside-induced lipid peroxidation in rat pancreas by water extractable phytochemicals from some tropical spices. Pharm. Biol. 2012a, 50(7): 857-865.

[3] Adegoke, G.O., Makinde, O., Falade, K.O., Uzo-Peters, P.I., Extraction and characterisation of antioxidants from Aframomum melegueta and Xylopia aethiopica Eur. Food Res. Technol. 2003, 216: 526-528.

[4] Adegoke, G.O., Skura, B.J., Nutritional, Profile and Antimicrobial Spectrum of the spice Aframomum danielli, plant food Human Nut., 1994, 45: 175-182.

[5] Allende, A., Tomas-Barberan, F.A., Gil, M.I., Minimal processing for healthy traditional foods. Trends in Food Science and Technology., 2006, 17: 513-519.

[6] Ali, H., Houghton, P.J., Soumyanath, A., Alpha amylase Inhibitory Activity of some Malaysian Plants used to Treat Diabetes; with Particular Reference to Phyllanthus amarus. J. Ethnopharmacol, 2006, 107: 449-455.

[7] Amano, Y., Kawakubo, K., Lee, J.S., Tang, A.C., Sugiyama, M., Mori, K., Correlation between Dietary Glycemic Index and Cariovascular Disease Risk Factors among Japanese Women. Eur J Clin Nutr., 2004, 58: 1472-1478.

[8] AOAC, Official Methods of Analysis of Association of Official Analytical Chemist International, Washington (D.C.). 2005.

[9] Aruna, P., Antioxidant Activity, Analytical Progress. Summer 2001. Takes you into the Heart of a Giant Resources, Medallion Laboratories, 2001, 19 (2). Pg. 1-6.

[10] Augustin, L.S., Franceshi, S., Jenkins, D.J.A., Kendall, C.W.C., La Vecchia, C., Glycemic index in chronic disease: a review. Eur J Clin Nutr., 2002, 56: 1049-1071.

[11] Aworh, O.C., and Olorunda, A.O., Packaging and Storing Technology of fresh fruits and vegetables with special references to tropical conditions. Proc. National Workshop on Improved Packaging and Storage system for fruits and vegetables in Nigeria. 1988,. Pg. 75-91.

[12] Baglieri, A., Mahe, S., Zidi, S., Huneau, J.F., Thuillier, F., Marteau, P., Tome, D., Gastro-jejunal digestion of soya-bean-milk protein in humans. Br J Nutr, 1994, 72: 519-532.

[13] Bhathena, S.J., Velasquez, M.T., Beneficial role of dietary phytoestrogens in obesity and diabetes. Am J Clin Nutr, 2002, 76: 1191-1201.

[14] Bos, C., Metges, C.C., Gaudichon, C., Petzke, K.J., Pueyo, M.E., Morens, C., Everwand, J., Benamouzig, R., Tome, D., Postprandial kinetics of dietary amino acids are the main determinant of their metabolism after soy or milk protein ingestions in humans. J Nutr, 2003, 133: 1308-1315.

[15] Carlsen, M.H., Halvorsen, B.L., Holte, K., Bohn, S.K., Dragland, S., Sampson, L., Willey, C., Senoo, H., Umezono, Y., Sanada, C., Barikmo, I., Berhe, N., Willet, W.C., Phillips, K.M., Jacobs, D.R., Blomhoff, R., The total herbs and supplements used worldwide. Nutr. J., 2010, 9(3): 1-11.

[16] Colombani, P.C., Glycemic Index and Load-dynamic Dietary Guidelines in the Context of Diseases. Physiol Behav., 2004, 83: 603-610.

[17] Corbo, M.R., Bevilacqua, A., Campaniello, D., D’Amato, D., Speranza, B., Sinigaglia, M., Prolonging microbial shelf life of foods through the use of natural compounds and non-thermal approaches- a review. International Journal of Food Science and Technology, 2009, 44: 223-241.

[18] Doherty, V.F., Olaniran, O.O., Kanife, U.C., Antimicrobial Activities of Aframomum melegueta (Alligator Pepper). Int. J. Biol., 2010, 2(2): 126-131.

[19] Elez, P., Soliva, R.C., Martins, O., Comparative study on shelf life of orange juice processed by high intensity pulsed electric fields or heat treatment. Euro Food Res Technol., 2006, 222: 321-9.

[20] Ezekwesili, C.N., Nwodo, O.F.C., Eneh, F.U., Ogbunugafor, H.A., Investigation of the chemical composition and biological activity of Xylopia aethiopica Dunal (Annonacae). Afr. J. Biotech., 2010, 9(43): 7352-7356.

[21] Fasoyiro, S.B., Adegoke, G.O., Obatolu, V.A., Ashaye, O., Aroyeun, S.O., The antioxidant property of Aframomum daniellia in oils. J. Food Technol. Africa, 2001a, 6: 135-137.

[22] Fasoyiro, S.B., Adegoke, G.O., Idowu, O.O., Characterisation and partial purification of Antimicrobial Components of Ethereal Fractions of Aframomum danielli. World J. Chem.1, 2006, (1): 1-5. (1994).

[23] Ford, E.S., liu, S., Glycemic Index and Serum High-Density Liproprotein, Cholesterol Concentration among US Adult. Arch Intern Med.: 2001, 161: 572-576.

[24] Foster-Powell, K., Holt, S.H., Brand-Miller, J.C., International table of glycemic index and glycemic load values: Am J Clin Nutr, 2002, 76: 5-56.

[25] Frost, G., Keogh, B., Smith, D., Akinsanya, K., Leeds, S., The Effect of Low-Glycemic Carbohydrate on Insulin and Glucose Response in Vivo and in Vitro in Patients with Coronary Heart Disease. Metabolism. 1996, 45: 669-672.

[26] Giacco, R., Parillo, M., Rivellese, A.A., Lasorella, G., Giacco, A., D’Episcopo, L., Riccardi, G., Long-term Dietary Treatment with Increased amounts of Fibre-rich low-glycemic Index Natural foods improves blood glucose control and reduces the number of hypoglycaemic control in children with type 1 diabetes. Diabetes Care. 2000, 23: 1461-1466.

[27] Hasler, C.M., The cardiovascular effects of soy products. J Cardiovasc. Nurs, 2002, 16: 50-63.

[28] Hodge, A.M., English, D.R., O’Dea, K., Giles, G.G., Glycemic Index and Dietary Fibre and the Risk of type 2 Diabetes. Diabetes Care. 2004, 27: 2701-2706.

[29] Howes, L.G., Howes, J.B., Knight, D.C., Isoflavone therapy for menopausal flushes: a systematic review and meta-analysis. Maturitas, 2006, 55: 203-211.

[30] Jarvi, A.E., Karlstrom, B.E. Granfeldt, Y.E., Bjorock, I.E., Asp, N.G., Vessby, B.O., Improved Glycemic Control and Lipid Profile and Normalized Fibrinolytic Acivity on a Low-Glycemic Index Diet in Type 2 Diabetic Patient. Diabetes Care. 1999, 22: 10-18.

[31] Jenkins, D.J., Wolever, T.M., Taylor, R.H., Glycemic Index of Foods: 1981, 34: 362-366.

[32] Jenkins, D.J., Jenkins, A.L., Wolever, T.M., Vuksan, V., Rao, A.V., Thompson, L.U., Josse, R.G., Low glycemic index: Lente Carbohydrates and Physiological Effects of altered Food Frequency. Am J Clin Nutr., 1994: 59(3 Suppl) 706S-709S.

[33] Jenkins, D.J., Wolever, T.M., Kalmusky, J., Guidici, S., Giordano, C., Patten, R., Wong, G.S., Bird, J.N., Hall, M., Buckley, G., LowGlycemic Index diet in Hyperlipidemia: Use of Traditional Starchy Foods. Am J Clin Nutr., 1987, 46: 66-71.

[34] Jenkins, D.J., Wolever, T.M., Collier, G.R., Ocana, A., Rao, A.V., Buckley, G., Lam, Y., Mayer, A., Thompson, L.U., Metabolic Effects of a Low-Glycemic-Index Diet. Am J Clin Nutr., 1987, 46: 968-975.

[35] Kim, J.S., Kwon, C.S., Son, K.H., Inhibition of AlphaGlucosidase and Amylase by Luteolin, a Flavonoid. Biosci. Biotechnol. Biochem., 2000, 64: 2458-2461.

[36] Kwon, Yi., Jang, H.D., Shetty, K., Evaluation of Rhodiola crenulata and Rhodiola Rosea for Management of Type II Diabetes and Hypertension. Asian Pac. J. Clin. Nutr., 2006, 15: 425-432.

[37] Ludwig, D.S., The Glycemic Index: Physiological Mechanisms Relating to Obesity, Diabetes and Cardiovascular Disease. JAMA. 2002, 287: 2414-23.

[38] Luscombe, N.D., Noakes, M., Clifton, P.M., Diet high and low in Glycemic Index versus High Monounsaturated Fat Diets: Effects on Glucose and Lipid Metabolism in NIDDM. Eur J Clin Nutr., 1999, 53: 473-478.

[39] Liu, S., Willett, W.C., Stampfer, M.J., Hu, F.B., Franz, M., Sampson, L., Hennekens, C.H., Manson, J.E.A., Prospective Study of Dietary Glycemic Load, Carbohydrate Intake and risk of Coronary Heart Disease in US Women Am J Clin Nutr., 2000, 71: 1455-1461.

[40] Liu, S., Manson, J.E., Burning, J.E., Stamper, M.J., Willet, W.C., Ridker, P.M., Relation between a Diet with a High Glycemic Load and Plasma Concentrations of High-Sensitivity C-Reactive Protein in Middle-aged Women. Am J Clin Nutr., 2002, 75: 492-498.

[41] Mariotti, F., Mahe, S., Benamouzig, R., Luengo, C., Dare, S., Gaudichon, C., Tome, D., Nutritional value of /15N/-soy protein Isolated Assessed From Ileal Digestibility And Postprandial Protein Utilization In Humans. J Nutr, 1999, 129: 1992-1997. 
[42] Merz, C.N.B., Johnson, B.D., Braunstein, G.D., Pepine, C.J., Reis, S.E., Paul-Labrador, M., Hale, G., Sharaf, B.L., Bittner, V., Sopko, G., Kelsey, S.F., For The Women'S Ischemia Syndrome Evaluation Study Group: Phytoestrogens And Lipoprotein In Women. J Clin. Endocrinol. Metab, (1994); 2006, 91: 2209-2213.

[43] Messina, M., Ho, S., Alekel, D.L., Skeletal Benefits Of Soy Isoflavones: A Review Of The Clinical Trial And Epidemiologic Data. Curr Opin Clin Nutr Metab Care, 2004, 7: 649-658.

[44] Miller, J.C., Importance Of Glycemic Index In Diabetes. Am J. Clin Nutr 59(3 Suppl): 1994, 747S-752S.

[45] Oboh, G., Ekperigin, M.M., Akindahunsi, A.A., Response Of Rat Liver Enzymes And Metabolites To Diet Supplemented With Some Nigerian Spices. Nig. J. Biochem. Mol. Biol. 2005, 20(2): 81-87.

[46] Oboh, G., Adefegha, S.A., Rochas, J.B.T., Fe2+ And Sodium Nitroprusside-Induced Oxidative Stress In Rat'S Brain (In Vitro): Protective Effect Of Aqueous Extract Of Mentha Viridis And Majarona Hotensis Leaves. Adv. Food Science. 2010a, 32(1): 1119.

[47] Oboh, G., Akinyemi, A.J., Ademiluyi, A.O., Antioxidant And Inhibitory Effect Of Red Ginger (Ziniber Officinale Var. Rubra) And White Ginger (Zingiber Officinaleroscoe) On Fe2+ Induced Lipid Peroxidation In Rat Brain- In Vitro: Exp. Toxicol. Pathol. 2012a, 64: 31-36.

[48] Oboh, G., Akinyemi, J.A., Ademuluyi, A.O., Adefegha, S.A., Inhibitory Effect Of Aqueous Extract Of Two Varieties Of Ginger On Key Enzymes Linked With Type-2 Diabetes. J. Food Nutri. Res. 2010b, 49(1): 14-20.

[49] Olivas, G.I., Barbosa-Canovas, G.V., Edible Coatings For FreshCut Fruits. Critical Reviews In Food Science And Nutrition. 2005, 45: 657-663.

[50] Olonisakin, A.O., Oladimeji, M.O., Lajide, L., Chemical Composition And Antibacterial Activity Of Steam Distilled Oil Of Ashanti Pepper (Piper Guineense) Fruits (Berries). Electric. J. Environ. Agric. Food Chem. 2006, 5(5): 1531-1535.

[51] Opperman, A.M., Venter, C.S., Oosthuizen, W., Thompson, R.L., Vorster, H.H., Meta-Analysis Of The Health Effects Of Using The Glycemic Index In Meal-Planning. Br J Nutr. 2004, 92: 367-381.

[52] Ortiz-Andrade, R.R., Garcia-Jimenez, S., Castillo-Espana, P., Rameriz-Vila, G., Villalobos-Molina, R., Estrada-Soto, S., AGlucodidase Inhibitory Activity Of The Methonolic Extract From Tourneforia Hartwegiana: An Anti-Hyperglycemic Agent. J. Ethnopharmacol, 2007, 109: 48-53.

[53] Rickman, J.C., Bruhn, C.M., Barette, D.M., Nutritional Comparison Of Fresh, Frozen And Canned Fruits And Vegetables. II. Vitamin A And Carotenoids, Vitamins E, Minerals And Fiber. J. Sci Food Agric (In Press). 2007b.

[54] Rickman, J.C., Bruhn, C.M., Barett, D.M., Nutritional Comparison Of Fresh, Frozen And Canned Fruits And Vegetables. Part 1. Vitamin C And B And Phenolic Compounds. J. Sci Food Agric (In Press). 2007a.

[55] Robert, M.B., Henley, E.C., Aaron, T., Soy Foods Low Glycemic And Insulin Response Indices In Normal Weight Subjects: Nutrition Journal, 2006, 5: 35.
[56] Salmeron, J., Ascherio, A., Rimm, E.B., Colditz, G.A., Spiegelman, D., Jenkins, D.J., Stampfer, M.J., Wing, A.L., Willett, W.C., Dietary Fiber, Glycemic Load And Risk Of NIDDM In Men. Diabetes Care. 1997, 20: 545-50.

[57] Salmeron, J., Manson, J.E., Stampfer, M.J., Colditz, G.A., Wing, A.L., Willett, W.C., Dietary Fiber, Glycemic Load And Risk Of Non-Insulin-Dependent Diabetes Mellitus In Women. JAMA. 1997, 277: 472-477.

[58] Sarkar, F.H., Li, Y., The Role Of Isoflavones In Cancer Chemoprevention. Front Biosci, 2004, 9: 2714-2724.

[59] Schulze, M.B., Liu, S., Rimm, E.B., Manson, J.E., Willett, W.C., Hu, F.B., Glycemic Index, Glycemic Load And Dietary Fibre Intake And Incidence Of Type 2 Diabetes In Younger And Middle-Aged Women. Am J Clin. Nutr. 2004, 80: 348-356.

[60] Shahidi, F., Naczk, M., Phenolics In Food And Nutraceuticals. Boca Raton, FL: CRC Press. 2004.

[61] Shan, B., Cai, Y.Z., Sun, M., Corke, H., Antioxidant Capacity Of 26 Spice Extracts And Characterisation Of Their Phenolic Constituents. J. Agric. Food Chem. 2005, 53(20): 7749-7759.

[62] Srinivasan, K., Sambaiah, K., Chandrassekhara, N., Spices As Beneficial Hypolipidemic Food Adjuncts: A Review. Food Rev. Int. 2004, 20: 187-220.

[63] Srinivasan, K., Role Of Spices Beyond Food Flavouring: Neutraceuticals With Multiple Health Effect. Food Rev. Int. 2005a, 21: $167-188$.

[64] Stampfer, M.J., Hu, F.B., Manson, J.E., Rimm, E.B., Willet, W.C., Primary Prevention Of Coronary Heart Disease In Women Through Diet And Lifestyle. New Engl J Med. 2000, 343: 16-22.

[65] Trock, B.J., Hilakivi-Clarke, L., Clarke, R., Meta-Analysis Of Soy Intake And Breast Cancer Risk. J Natll Inst, 2006, 459-471.

[66] Uwakwe, A.A., Nwaoguikpe, R.N., In Vitro Antisickling Effects Of Xylopia Aethiopica And Monodora Myristica. J. Med. Plants Res. 2008, 2(6): 119-124.

[67] Warren, J.M., Henry, C.J., Simonite, V., Low Glycemic Index Breakfast And Reduced Food Intake In Preadolescent Children. Paediatrics. 2003, 112: E414.

[68] Wojdylo, A., Oszmianski, J., Czemerys, R, Antioxidant Activity And Phenolic Compounds In 32 Selected Herbs. Food Chem. 2007, 105(3): 940-949.

[69] Wolever, T.M., Vorster, H.H., Bjorck, I., Brand-Miller, J., Brighenti, F., Mann, J.I., Ramdath, D.D., Granfeldt, Y., Holt, S., Perry, T.L., Venter, C., Xiaomei, W, Determination Of The Glycaemic Index Of Foods: Interlaboratory Study. Eur J Clin Nutr, 2003, 57: 475-482.

[70] Yan, L., Spitznagel, E.L., Meta-Analysis Of Soy Food And Risk Of Prostrate Cancer In Men. Int J Cancer, 2005, 117: 667-669.

[71] Young, V.R., Puig, M., Queiroz, E., Scrimshaw, N.S., Rand, W.M., Evaluation Of The Protein Quality Of An Isolated Soy Protein In Young Men: Relative Nitrogen Requirements And Effects Of Methionine Supplementation. Am J Clin Nutr, 1984, 39 16-24.

[72] Zhan, S., Ho SC, Meta-Analysis Of The Effects Of Soy Protein Containing Isoflavones On The Lipid Profile. Amer. J Clin. Nutr, 2005, 81: 397-408. 